\title{
The Mathematics of the Contagion: Applications of the SIR Model in the Study of Pandemics
}

\author{
Marta Covadonga Mora-Aguilar ${ }^{\text {a }}$, \& Joaquín Cerdá Boluda ${ }^{\text {b }}$
}

Received: 24 February $2020 \bullet$ Accepted: 28 February 2020

\begin{abstract}
At a first glance, the epidemics phenomenon seems to be enormously complex, especially if we consider the number of factors that can influence its appearance and evolution. However, within the scope of complex systems, certain approximations and abstractions can be made when addressing the problem with the aim of simplifying the study without resigning the possibility of drawing interesting conclusions about the phenomenon. This article presents the foundations of the mathematical modeling applied to the study of pandemics, taking as its guiding principle the simplest and most widely used model, the SIR model, to subsequently introduce some modifications that increase its scope.
\end{abstract}

Key-words: Pandemic, Contagiousness, Complex Systems, Mathematical Modeling, SIR Model.

\section{Introduction}

The complex systems field is a fascinating knowledge area, being its main goal the representation of models with many involved factors for which the traditional study approaches are insufficient. Surprisingly, a well-posed model of a phenomenon is able of reproducing a large part of the complex behaviors observed in the real life with very few parameters. Competition between species, extinctions, phylogenetic trees, distribution of natural resources or percolation phenomena, etc., the type of situations that can be described through the formalism of these systems is enormous and fascinating are the conclusions that they throw.

\footnotetext{
a Jaume I University (Spain). (DORCID 0000-0003-0627-6764. ${ }^{\mathrm{b}}$ Polytechnic University of Valencia (Spain). (DORCID 0000-0002-6649-298X. Correspondence: Universidad Jaume I. Av. Vicent Sos Baynat, s/n 12071 Castellón de la Plana (Spain). mmora@uji.es
} 
In the following sections we will focus on epidemics models. For that purpose, we will start from a classic case, the SIR model, which is now exposed as an example in numerous texts on differential equations. Starting from this model, some modifications will be introduced to allow its application to real cases, increasing its scope.

\section{The SIR model}

To study the spread of an epidemic in terms of system dynamics, the simplest model that can be used is the so-called SIR model, introduced almost a century ago by Kermack and McKendrick (1927).

The model is very simplified and suffers from some important problems that we will try to avoid later. Probably the biggest one is that it does not consider the possibility of death of people in a population and, therefore, epidemics are never fatal. Some modifications can be included to make it more realistic. For now, let's separate the total population of an environment into three different categories.

The first category to consider would be composed of the healthy or Susceptible people, for whom we could use the variable $\mathrm{S}$ in the equations. These people have not yet been infected by the pathogen.

The second category would be composed of the Infected people, to which we will refer by means of the variable I.

Finally, those people who have already suffered from the disease and have recovered from it (of have died, as these people are not included in a separate category) would appear in the Recovered category, identified by the variable $\mathrm{R}$.

The aim of systems dynamics is to obtain a series of laws describing how the three variables change over time (Aracil \& Gordillo, 1997). Let's see how this is possible.

Let's introduce parameter $\beta$, which is the infection parameter and models the fact that an Infected person infects a healthy or Susceptible person. It is easy to conclude that the infection rate, namely IR, will increase with the number of healthy or susceptible people, the number of Infected people and, of course, the greater the probability of infection. Thus, IR is directly proportional to these three quantities, which can be mathematically expressed by the following equation:

$$
T I=\beta \cdot S \cdot I
$$

On the other hand, there are infected people who eventually recover. Let's calculate the recovery rate RR and, for this, let's introduce a new parameter $\gamma$, which represents the probability that an infected person stops 
being infected. The recovery rate will directly depend on the number of infected people:

$$
T R=\gamma \cdot l
$$

The introduced rates alter the three populations, a fact that can be expressed through a series of differential equations. These type of equations allow variations in populations to be modeled as functions of time. For the model to be affordable, it has to be assumed that populations only depend on these parameters, and not on other external ones. For example, the existence of births or deaths in the system is not taken into account. These assumptions which, at first glance, may seem very restrictive, are not so restrictive if they are considered to be phenomena that develop on different time scales. In general, the spread of a disease is a relatively rapid phenomenon compared to "natural" deaths and births.

Let us pose the equations. The population of healthy or Susceptible people decreases with the infection rate:

$$
\frac{d S}{d t}=-T I
$$

The population of Infected people varies for two reasons: a) it increases with the infection rate, $b$ ) it decreases with the recovery rate:

$$
\frac{d I}{d t}=T I-T R
$$

Finally, the population of Recovered people grows with the recovery rate:

$$
\frac{d R}{d t}=T R
$$




\section{What do equations say?}

The above-mentioned reasoning leads to a system of three differential equations that we can now compile, after eliminating intermediate variables and resorting only to the quantities of interest.

$$
\begin{gathered}
\frac{d S}{d t}=-\beta \cdot S \cdot I \\
\frac{d l}{d t}=\beta \cdot S \cdot I-\gamma \cdot I \\
\frac{d R}{d t}=\gamma \cdot I
\end{gathered}
$$

There is no doubt that it is an elegant description of a phenomenon as complex as the spread of an epidemic, but what does it have to say? What information can be extracted from these three equations?

The answer to this question lies in the resolution of the system of equations, not always an easy matter. The equations obtained are non-linear, which makes the analytical work extremely difficult, since this type of equations cannot be solved in a straightforward manner.

Fortunately, for a long time, mathematicians have managed to deal with this type of equations by means of numerical approximations, which basically consist of dividing time and space into tiny intervals and applying certain simplifications to the equations to make them tractable (Hughes-Hallett, 2017). The process is especially successful when, in addition, highperformance computing machines are used, such as computers, capable of performing many calculations in a short period of time. Nowadays, the field of numerical calculation presents a fervent and very prominent activity (Gerald y Wheatley, 2003).

The resolution of these equations makes it clear that the quantitative behavior of the system depends largely on the values assigned to the parameters $\beta$ and $\gamma$. But qualitatively, the behavior is easily interpretable and can be seen in Figure 1. It shows how the infected population grows to a maximum and then decreases until its complete disappearance. In the equilibrium state, the total population is reduced to two categories: those who suffered from the disease and those who did not.

The resolution of these equations makes it clear that the quantitative behavior of the system depends largely on the values assigned to the parameters 
$\beta$ and $\gamma$. But qualitatively, the behavior is easily interpretable and can be seen in Figure 1. It shows how the infected population grows to a maximum and then decreases until its complete disappearance. In the equilibrium state, the total population is reduced to two categories: those who suffered from the disease and those who did not.

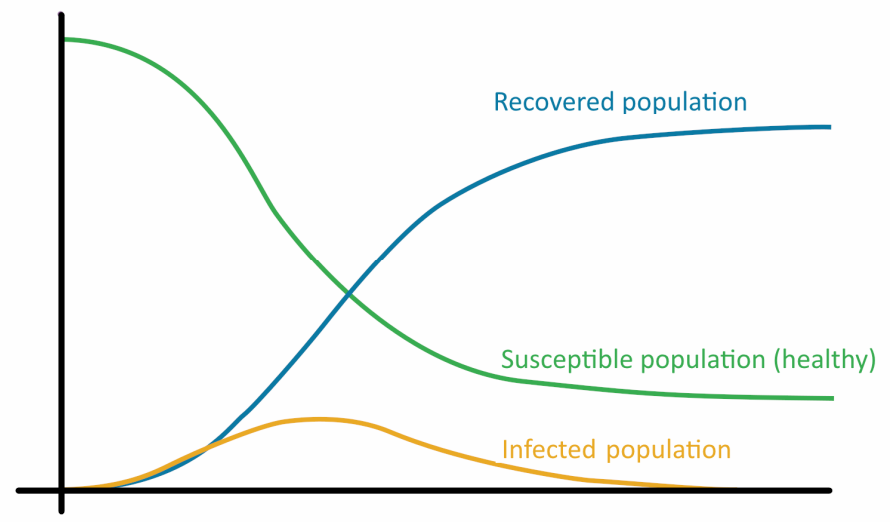

Figure 1. Typical behavior of the SIR model. The green trace corresponds to healthy or susceptible individuals. The blue trace represents the recovered population. The yellow trace describes infected individuals

\section{Mortal diseases}

The simple SIR model can be completed in order to introduce the probability of death of the infected population (Segarra, 2002).

Let us return to the three population categories, but now let us slightly modify their definition. First, the healthy or Susceptible population will be again modelled by the variable $\mathrm{S}$. These people have not yet been infected by the pathogen.

Secondly, the sick and infected people will be modelled by means of variable $\mathrm{C}$.

Lastly, for the infected but not sick people we can use the variable $\mathrm{N}$.

It is necessary to be very clear about the difference between the last two categories, discriminating the infection, which consists in capturing the disease-transmitting agent, and the sickness, which is the development of the disease as a result of the infection.

As the model is a little more complex, it is convenient to express the relationship between these variables by means of a graph known as a causal diagram, shown in Figure 2. Several assumptions can be extracted from this diagram: a) The flow of contagion increases with the population, both the sick and the healthy, b) The sick population increases with the flow of contagion, and c) The healthy population increases with the total population. 


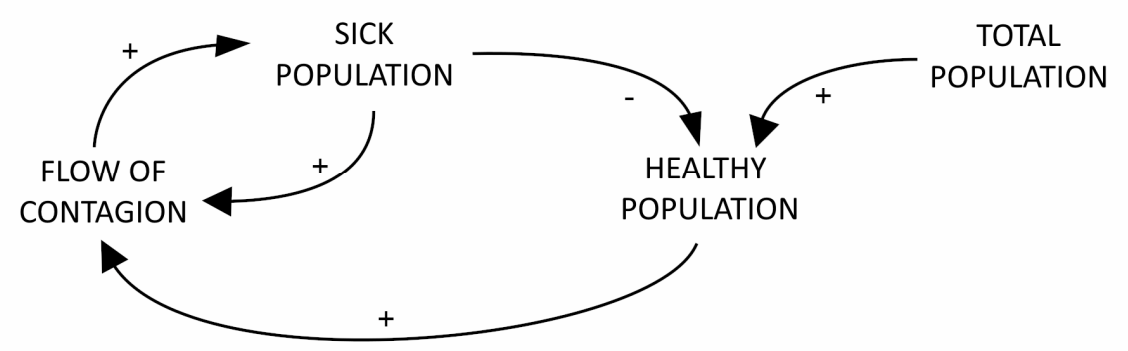

Figure 2. Relationship between variables in the epidemiological model with deaths.

As before, $\beta$ represents the infection parameter of an infected person to a healthy person. We will thus obtain the same infection rate.

$$
T I=\beta \cdot S \cdot C
$$

Regarding the infected people that are not sick, a brief reflection leads us to intuit that they come from two different contributions. On the one hand, from those people immune to the disease that, although they receive the virus, do not develop it. On the other hand, there is also the possibility that a person receives the virus and does not develop the disease because the person was previously sick.

Each of these quantities has a very simple expression in mathematical terms. We will use the variable NIR to model the non-infection rate. Infection from infected to not sick is the product of the respective populations:

$$
T N C_{1}=\beta \cdot N \cdot C
$$

While the infection from sick to sick people would follow the same scheme, but subtracting an element from the sick population (because an infected person cannot infect himself):

$$
T N C_{2}=\beta \cdot \mathrm{C} \cdot(C-1)
$$

Finally, there is the probability of death. We will model this probability using the $\mathrm{p}_{\mathrm{d}}$ parameter. This possibility leads to a death rate, DR, higher the greater the population of sick people:

$$
T M=p_{m} \cdot \mathrm{C}
$$


Let's go to the equations. As we already know, the population of healthy or Susceptible people decreases with the infection rate:

$$
\frac{d S}{d t}=-T l
$$

The sick population changes for several reasons: a) it grows with the infection rate, b) it decreases with the non-infection rate, in its two contributions, and c) it decreases with the death rate:

$$
\frac{d C}{d t}=T I-T N C_{1}-T N C_{2}-T M
$$

And finally, the population of infected but not sick grows with the noninfection rate, in its two contributions:

$$
\frac{d N}{d t}=T N C_{1}+T N C_{1}
$$

\section{Possible scenarios}

The new system of equations is similar, although slightly different, to the previously obtained for the SIR model.

$$
\begin{gathered}
\frac{d S}{d t}=-\beta \cdot S \cdot C \\
\frac{d C}{d t}=\beta \cdot S \cdot C-\beta \cdot N \cdot C-\beta \cdot C \cdot(C-1)-p_{m} \cdot C
\end{gathered}
$$




$$
\frac{d N}{d t}=\beta \cdot N \cdot C+\beta \cdot C \cdot(C-1)
$$

What does this new modification reflect? The resolution of these equations makes it clear that the behavior of the system largely depends on the values assigned to the parameters. But now this dependency is not just quantitative, but also qualitative, and can lead to completely different scenarios. Some of these scenarios, curiously, may challenge our own intuition.

Let us describe several illustrative situations. Suppose a not very virulent epidemic, represented by a probability of death of $20 \%$. Figure 3 shows the evolution of the population, separated in the different categories. We can see that, beyond the peak of infections, the total population stabilizes at values that represent a decimation of approximately $25 \%$ of the initial population.

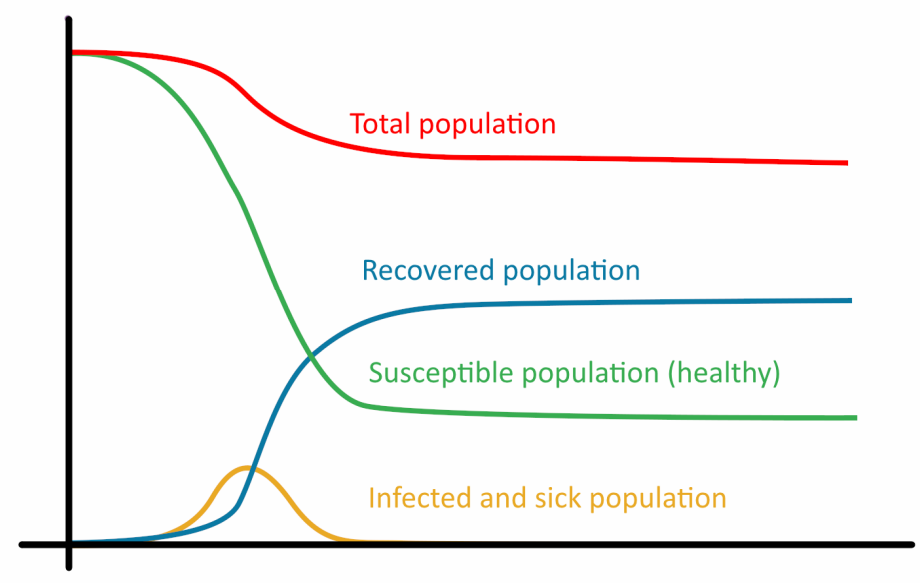

Figure 3. Behavior of an epidemiological model with deaths of low virulence. The red trace represents the total population, the green trace represents the susceptible population, the yellow trace represents the infected and sick population and the blue trace the recovered population.

If the virulence of the pandemic increases, common sense leads us to believe that the destruction of the population will be more intense, and indeed it is. We can see in figure 4 , in which the probability of death has been increased to $50 \%$, that the initial population has been reduced to less than a half. 


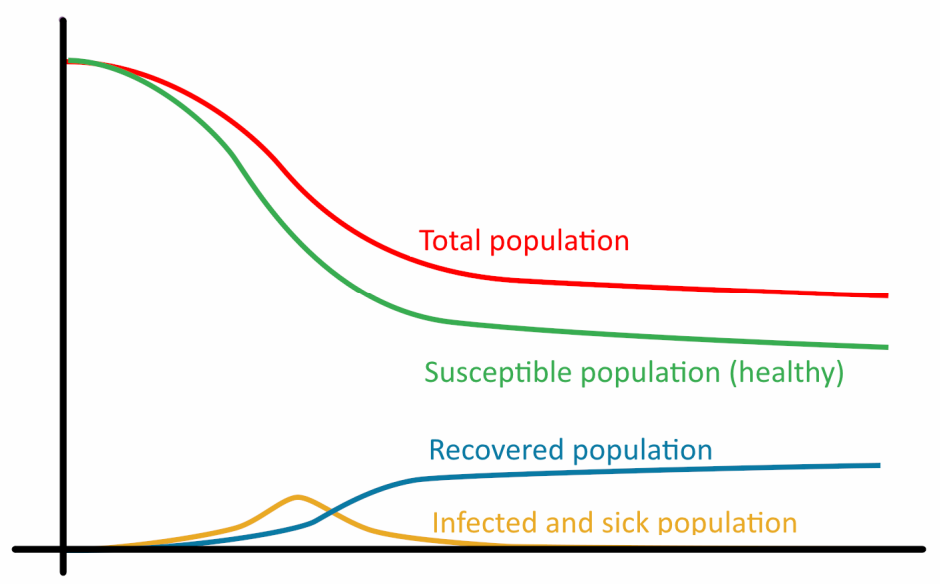

Figure 4. Behavior of an epidemiological model with deaths of medium virulence.

But what happens further? If we increase the epidemic virulence and test an $80 \%$ probability of death, the result is surprising, since the number of deaths is reduced, as shown in Figure 5.

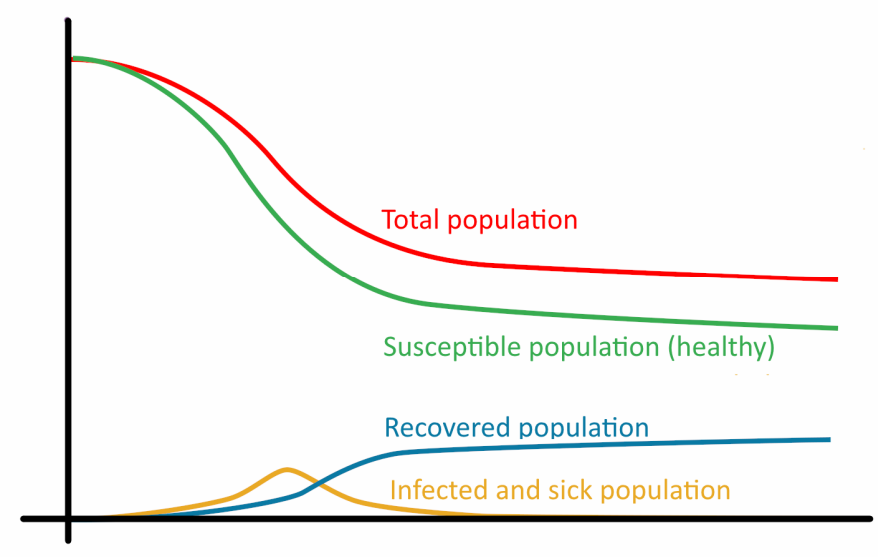

Figure 5. Behavior of an epidemiological model with deaths of high virulence.

What is the reason for this paradox? The explanation lies precisely in the fulminant dynamics of the virus. With these death rates, sick individuals are unlikely to infect others before dying, leading to a decrease in the number of infections.

A sinister note regarding the conclusions of this model: in certain scenarios, it can be effective to maximize the probability of death in order to 
reduce infections. However, when we refer to epidemics affecting the human being, this type of solution is inadmissible due to ethical and moral considerations, but it can offer suggestions regarding animal or plant pandemics.

\section{Conclusions}

The science of complex systems has a lot to say regarding situations with which, as a species, we are bound to deal at some point in our evolution. Nowadays, the mathematical and computational tools available make it possible for researchers to tackle problems with multiple factors that, even in their most abstract and simplified versions, contain powerful and suggestive conclusions. The use of computing devices and, above all, the availability of an increasingly large amount of data will allow that researchers develop, step by step, more realistic models that provide crucial evidence regarding how governments should act in cases that require intervention.

The phenomenon of epidemics is a paradigmatic case in this regard. With very few parameters, it is possible to capture the essence of a massive phenomenon, sadly present in today's world and with often devastating consequences. It is in our hands to invest efforts in improving the degree of knowledge of the phenomenon through its study and mathematical modeling.

\section{References}

Kermack, W. O., \& McKendrick, A. G. (1927). A Contribution to the Mathematical Theory of Epidemics. In VV.AA. Proceedings of the royal society of london. Series A, Containing papers of a mathematical and physical character, 115(772), 700-721.

Aracil, J., \& Gordillo, F. (1997). Dinámica de Sistemas (1 $1^{\mathrm{a}}$ ed.). Madrid: Alianza Editorial.

Hughes-Hallett, D., Lock, P. F., Gleason, A. M., Flath, D. E., Gordon, S. P., Lomen, D. O., et al. (2017). Applied Calculus. Toronto: John Wiley \& Sons.

Gerald, C. F., \& Wheatley, P. O. (2003). Applied Numerical Analysis ( $7^{\mathrm{a}}$ ed.). London: Pearson.

Segarra, J. G. (2002). Vida artificial: del caos al orden. Alzira: Algar. 


\title{
La matemática del contagio: aplicaciones del modelo SIR en el estudio de pandemias
}

\author{
Marta Covadonga Mora-Aguilar ${ }^{\text {a }}$
}

Recibido: 24 Febrero 2020 • Aceptado: 28 Febrero 2020

Resumen: A primera vista, el fenómeno de las epidemias parece ser de una enorme complejidad, si tenemos en cuenta la cantidad de factores que pueden influir en su aparición y evolución. Sin embargo, dentro del ámbito de los sistemas complejos, es posible realizar ciertas aproximaciones y abstracciones a la hora de abordar el problema de forma que se simplifique el estudio sin renunciar a la posibilidad de extraer interesantes conclusiones sobre el fenómeno. En este artículo se exponen los fundamentos de la modelización matemática aplicada al estudio de pandemias, tomando como hilo conductor el modelo más sencillo y empleado, el modelo SIR, para, posteriormente, introducir algunas modificaciones que aumenten su ámbito de aplicación.

Palabras Clave: Pandemia, Contagio, Sistemas Complejos, Modelización Matemática, Modelo SIR.

\section{Introducción}

El área que se ha venido a denominar los sistemas complejos es un área fascinante. Su objetivo último es el de ser capaz de representar modelos con muchos actores para los que las aproximaciones de estudio tradicionales son insuficientes. De un modo sorprendente, se constata que, con muy pocos parámetros, si un modelo de un fenómeno está bien planteado es capaz de reproducir gran parte de los comportamientos complejos que se observan en la realidad. Competición entre especies, extinciones, árboles filogenéticos, distribución de recursos naturales o fenómenos de percolación... el tipo de situaciones que pueden ser descritas a través del formalismo de estos sistemas es enorme y las conclusiones que arrojan, fascinantes.

a Universitat Jaume I, Departamento de Ingeniería Mecánica y Construcción. Av. Vicent Sos Baynat, s/n 12071 Castellón de la Plana (España). mmora@uji.es. (D) ORCiD 0000-0003-06276764. 
A continuación centraremos nuestras miradas en los modelos de epidemias. Para ello, partiremos de un caso clásico, el modelo SIR, hoy expuesto como ejemplo en numerosos textos de ecuaciones diferenciales. A partir de este modelo, introduciremos algunas variaciones que nos permitan aplicarlo a casos reales y que aumenten su rango de utilidad.

\section{EI modelo SIR}

Para estudiar la propagación de una epidemia en términos de dinámica de sistemas, el modelo más sencillo que se puede emplear es el denominado modelo SIR, introducido hace casi un siglo por Kermack y McKendrick (1227).

El modelo resulta muy simplificado y adolece de algunos problemas que, más adelante, intentaremos soslayar. Probablemente el mayor de estos problemas es que no considera la posibilidad de muerte de personas de una población, de modo que las epidemias nunca son fatales. Pero más adelante podemos ver cómo modificar esto para tornarlo más realista. De momento, separemos la población total de un entorno en tres categorías diferentes.

La primera categoría a considerar sería la de personas Sanas o Susceptibles, para las que podríamos emplear, en las fórmulas, la variable $S$. Estas personas todavía no han sido infectadas por el elemento patógeno.

La segunda categoría sería la de personas Infectadas, a las que nos referiremos mediante la variable $I$.

Por último, aquellas personas que ya han sufrido la enfermedad y que se han recuperado aparecerían en la categoría de Recuperadas, identificadas mediante la variable $R$.

El objetivo de la dinámica de sistemas consiste en obtener una serie de leyes que describan cómo varían las tres cantidades planteadas a lo largo del tiempo (Aracil y Gordillo, 1997). Veamos cómo es posible realizar esto.

Introduzcamos el parámetro $\beta$, que es la tasa de infección y modeliza el hecho de que una persona Infectada contagie a una Sana. Es sencillo llegar a la conclusión de que la tasa de personas Infectadas, a la que podemos llamar $T I$, es mayor cuanta más gente Sana hay. TI también es mayor cuanta más gente Infectada hay. Y, por supuesto, TI también crece en el mismo sentido que la probabilidad de infección. De este modo, $T I$ es directamente proporcional a estas tres cantidades, lo que puede expresarse matemáticamente mediante la siguiente fórmula.

$$
T I=\beta \cdot S \cdot I
$$

Por su parte, están los infectados que, eventualmente, se recuperan. Calculemos la tasa de recuperación $T R$ y, para ello, introduzcamos el paráme- 
tro $\gamma$, que representa la probabilidad de que un infectado deje de estarlo. La tasa de recuperación dependerá directamente del número de personas infectadas:

$$
T R=\gamma \cdot I
$$

Las cantidades introducidas alteran las tres poblaciones, hecho que se puede plasmar mediante una serie de ecuaciones diferenciales, que son ecuaciones que permiten establecer el cambio en función del tiempo. Para que el modelo sea asequible es necesario asumir que las poblaciones solo dependen de estos parámetros, y no de otros externos. Por ejemplo, no se tiene en cuenta la existencia de nacimientos o fallecimientos en el sistema. Estas suposiciones, que a primera vista pueden parecer muy restrictivas, no lo son tanto si se considera que son fenómenos que se desarrollan en distintas escalas de tiempo. En general, la propagación de una enfermedad es un fenómeno relativamente rápido comparado con las muertes y los nacimientos "naturales".

Planteemos, pues, las ecuaciones. La población de personas Sanas decrece con la tasa de infectados:

$$
\frac{d S}{d t}=-T I
$$

La población de personas Infectadas varía por dos motivos: a) crece con la tasa de infectados, b) decrece con la tasa de recuperados:

$$
\frac{d I}{d t}=T I-T R
$$

Y, por último, la población de personas Recuperadas crece con la tasa de recuperados:

$$
\frac{d R}{d t}=T R
$$




\section{Desarrollo de las ecuaciones}

Todos los razonamientos anteriores se han plasmado en un sistema de tres ecuaciones diferenciales que podemos recopilar ahora, eliminando las variables intermedias y recurriendo sólo a las cantidades que nos interesan.

$$
\begin{gathered}
\frac{d S}{d t}=-\beta \cdot S \cdot I \\
\frac{d I}{d t}=\beta \cdot S \cdot I-\gamma \cdot I \\
\frac{d R}{d t}=\gamma \cdot I
\end{gathered}
$$

No hay duda de que constituye una descripción elegante de un fenómeno tan complejo como la expansión de una epidemia, pero, ¿qué tiene que decirnos? ¿qué información se puede extraer a partir de estas tres fórmulas?

Para responder a esta pregunta es necesario resolver el sistema de ecuaciones, asunto que no siempre es sencillo. En este caso, las ecuaciones obtenidas son claramente no lineales, lo que complica en extremo el trabajo analíti$\mathrm{co}$, dado que no pueden resolverse de manera directa.

Por fortuna, desde hace mucho tiempo, los matemáticos han conseguido lidiar con este tipo de problemas realizando aproximaciones numéricas, las cuales consisten, básicamente, en dividir el tiempo y el espacio en intervalos diminutos y aplicar determinadas aproximaciones a las ecuaciones para que sean sencillas de tratar (Hughes-Hallett, 2017). El proceso se muestra especialmente beneficioso cuando, además, se recurre a máquinas de cómputo de elevadas prestaciones, como los ordenadores, capaces de realizar multitud de cálculos en un breve lapso temporal. El campo del cálculo numérico presenta una ferviente y muy destacada actividad en la actualidad (Gerald y Wheatley, 2030).

La resolución de estas ecuaciones deja claro que el comportamiento cuantitativo del sistema depende en gran medida de los valores asignados a los parámetros $\beta$ y $\gamma$. Pero cualitativamente, el comportamiento es fácilmente interpretable y se puede ver en la Figura 1. En ella se ve cómo la población de infectados crece hasta un máximo, momento a partir del cual decrece hasta desaparecer. En el estado de equilibrio, la población total queda reducida a dos categorías: aquellos que sufrieron la enfermedad y los que no. 


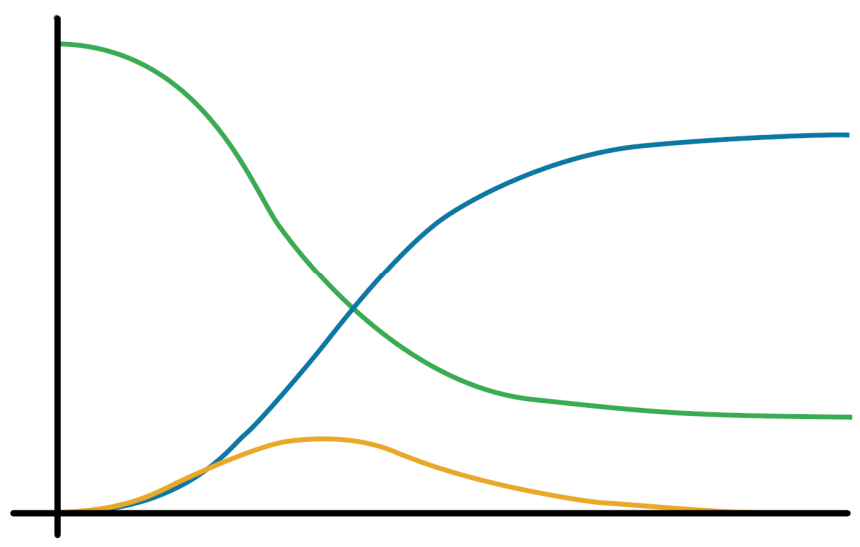

Figura 1. Comportamiento típico del modelo SIR. La traza verde corresponde a los individuos sanos. La traza azul representa a la población recuperada. La traza naranja describe a los individuos infectados

\section{Enfermedades mortales}

El sencillo modelo SIR puede ser completado para introducir la probabilidad de muerte de los infectados (Segarra, 2002).

De nuevo volvemos a las tres categorías poblacionales, pero ahora vamos a modificar ligeramente su definición. En primer lugar, estarían las personas a las que podemos denominar Sanas y emplear, en las fórmulas, la variable $S$. Estas personas todavía no han sido infectadas por el elemento patógeno.

En segundo lugar, aparecerían las personas infectadas y contagiadas, a las que nos referiremos mediante la variable $C$.

Por último, tenemos aquellas personas infectadas, pero no contagiadas, con las que podremos emplear la variable $N$.

Hay que tener bien clara la distinción entre las dos últimas categorías diferenciando la infección, que consiste en captar al agente transmisor de la enfermedad, del contagio, que es el desarrollo de la enfermedad a resultas de la infección.

Como el modelo es un tanto más complejo, es conveniente expresar la relación entre estas variables mediante un gráfico conocido como diagrama causal, mostrado en la figura 2. En este esquema quedan claras varias cosas: a) Que el flujo de contagio aumenta con la población, tanto la enferma como la sana, b) Que la población enferma aumenta con el flujo de contagio, y c) Que la población sana aumenta con la población total. 


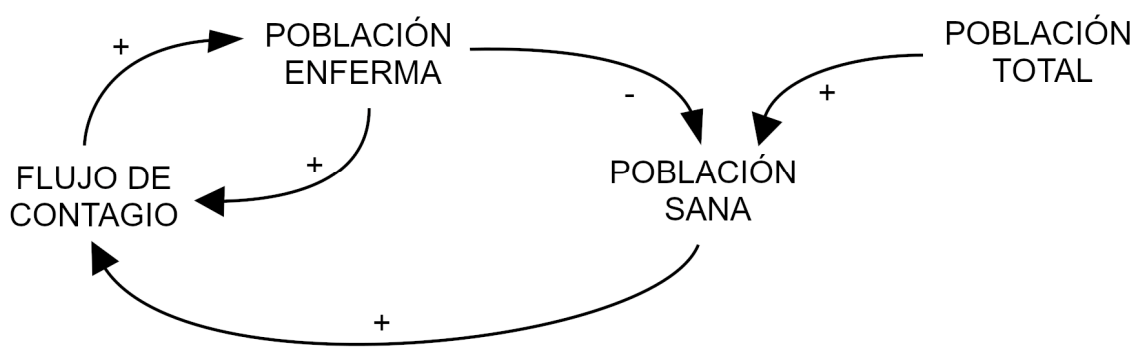

Figura 2. Relación entre cantidades en el modelo epidemiológico con muertes

Como antes, $\beta$ representará el parámetro de infección de una persona Contagiada a una Sana. Obtendríamos, pues, la misma tasa de infección.

$$
T I=\beta \cdot S \cdot C
$$

Respecto a los infectados no contagiados, una breve reflexión nos lleva a intuir que provienen de dos contribuciones diferentes. Por una parte, estarían aquellas personas inmunes a la enfermedad que, aunque reciban el virus, no la desarrollan. Pero también existe la posibilidad de que una persona reciba el virus y no desarrolle la enfermedad porque ya estaba enfermo previamente.

Cada una de estas cantidades tiene una expresión muy sencilla en términos matemáticos. Llamaremos TNC a la tasa de no contagiados. La infección de contagiados a no contagiados es el producto de las respectivas poblaciones:

$$
T N C_{l}=\beta \cdot N \cdot C
$$

Mientras que la infección de contagiados a contagiados seguiría el mismo esquema, pero restando un elemento a la población de contagiados (porque un contagiado no puede contagiarse a sí mismo):

$$
T N C_{2}=\beta \cdot \mathrm{C} \cdot(C-1)
$$

Por último, existe la probabilidad de fallecimiento. Modelizaremos esta mediante el parámetro $p_{m}$. Esta posibilidad deriva en una tasa de muertes, $T M$, mayor cuanto mayor es la población de contagiados:

$$
T M=p_{m} \cdot \mathrm{C}
$$

Vayamos a las ecuaciones. Como ya sabemos, la población de Sanos decrece con la tasa de infectados: 


$$
\frac{d S}{d t}=-T l
$$

La población de Contagiados varía por varios motivos: a) crece con la tasa de infectados, b) decrece con la tasa de no contagiados, en sus dos contribuciones, y c) decrece con la tasa de muertes:

$$
\frac{d C}{d t}=T I-T N C_{1}-T N C_{2}-T M
$$

Y, por último, la población de infectados No contagiados crece con la tasa de no contagiados, en sus dos contribuciones:

$$
\frac{d N}{d t}=T N C_{1}+T N C_{2}
$$

\section{Posibles escenarios}

El nuevo sistema de ecuaciones es similar, aunque ligeramente distinto, al que obtuvimos en el modelo SIR.

$$
\begin{gathered}
\frac{d S}{d t}=-\beta \cdot S \cdot C \\
\frac{d C}{d t}=\beta \cdot s \cdot C-\beta \cdot N \cdot C-\beta \cdot C \cdot(C-1)-p \times \cdot C \\
\frac{d N}{d t}=\beta \cdot N \cdot C+\beta \cdot C \cdot(C-1)
\end{gathered}
$$


¿Qué nos plantea esta nueva modificación? La resolución de estas ecuaciones deja claro que el comportamiento del sistema depende en gran medida de los valores asignados a los parámetros. Pero ahora esta dependencia no es simplemente cuantitativa, sino también cualitativa, y puede llevar a escenarios completamente distintos. Algunos de estos escenarios, curiosamente, desafían nuestra propia intuición.

Planteemos varias situaciones ilustrativas. Supongamos una epidemia no demasiado virulenta, representada en el hecho de que asignamos una probabilidad de muerte del $20 \%$. En la figura 3 se aprecia cómo evoluciona la población que, más allá del pico de infecciones, se estabiliza en unos valores que suponen un diezmado de, aproximadamente, el $25 \%$ del total.

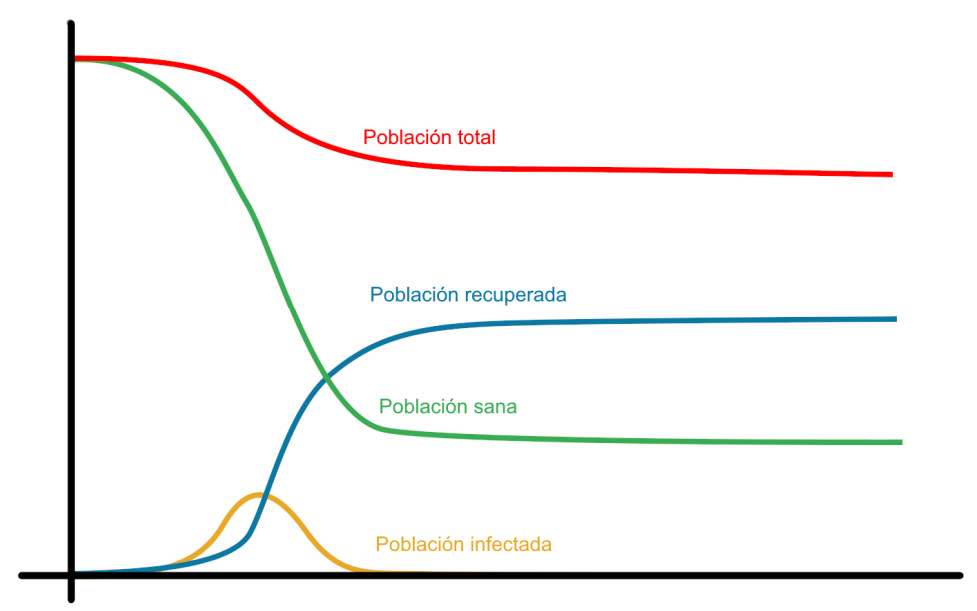

Figura 3. Comportamiento del modelo epidemiológico con muertes a baja virulencia. La traza roja representa la población total

Si la virulencia de la pandemia se incrementa, el sentido común parece llevarnos a pensar que el diezmado poblacional será más intenso, y así es. Vemos en la figura 4, en la que se ha aumentado la probabilidad de muerte al $50 \%$, que la población inicial ha quedado reducida a menos de la mitad. 


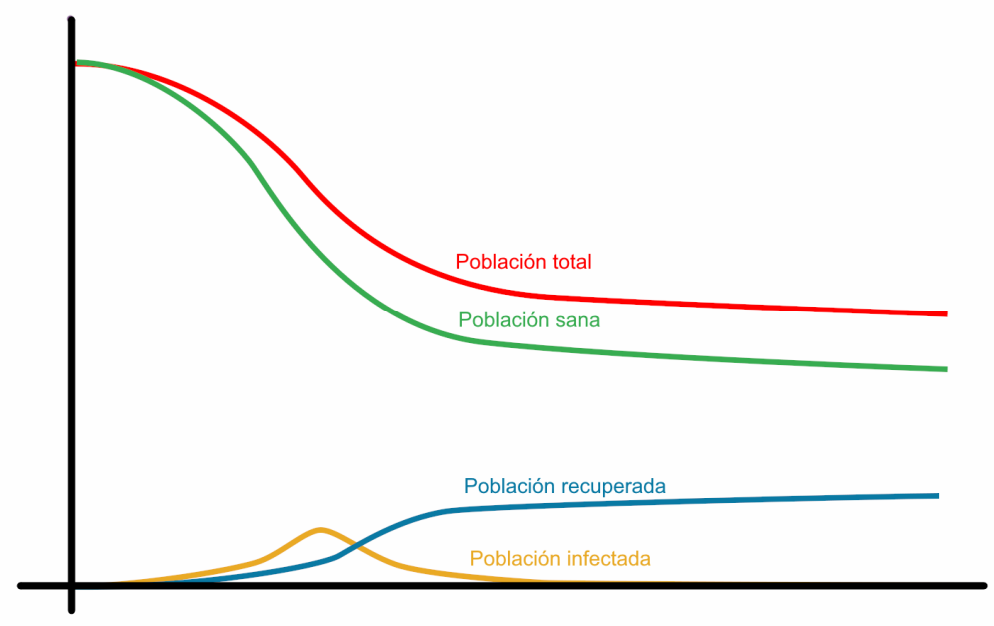

Figura 4. Comportamiento del modelo epidemiológico con muertes a media virulencia

Pero, ¿qué sucede más allá? Si elevamos la virulencia de la epidemia y ensayamos una probabilidad de muerte del $80 \%$, el resultado es sorprendente, pues el número de muertes se ve reducido, tal como se aprecia en la figura 5.

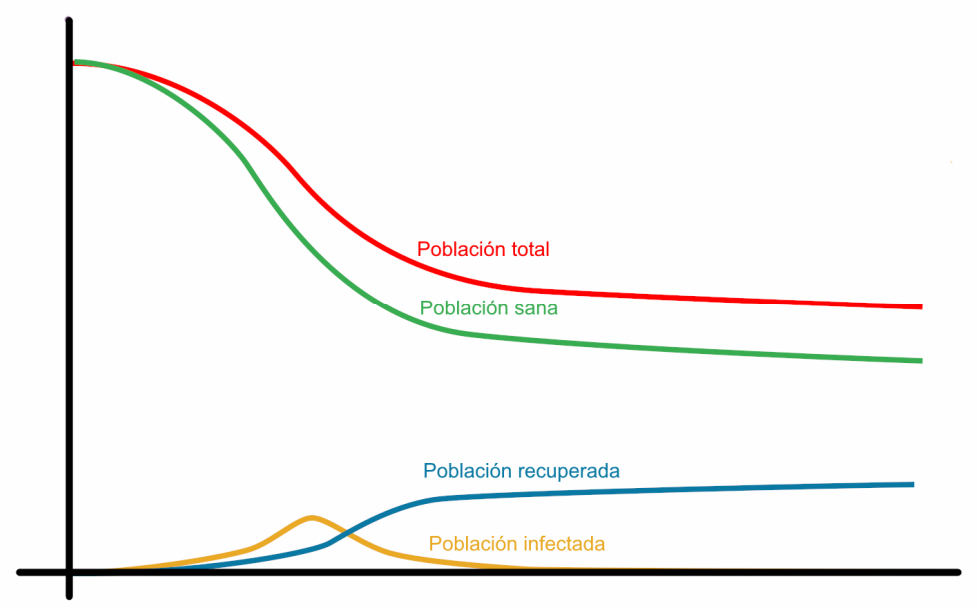

Figura 5. Comportamiento del modelo epidemiológico con muertes a alta virulencia.

¿A qué se debe esta aparente paradoja? La explicación reside, precisamente, en la dinámica fulminante del virus. Con esas tasas de mortandad, los individuos contagiados tienen pocas probabilidades de contagiar a otros antes de fallecer, lo que deriva en una disminución del número de contagios. 
Un apunte siniestro respecto a las conclusiones que arroja este modelo; en determinados escenarios, puede ser eficaz, pues, maximizar la probabilidad de muerte con el fin de reducir los contagios. Está claro que, cuando nos referimos a epidemias que afecten al ser humano, este tipo de resoluciones es inadmisible por simples consideraciones de carácter ético y moral, pero puede arrojar sugerencias en lo referente a pandemias de animales o plantas.

\section{Conclusiones}

La ciencia de los sistemas complejos tiene mucho que decir en lo referente a situaciones con las que, como especie, estamos abocados a lidiar en algún momento de nuestra evolución. Hoy en día, las herramientas matemáticas y de cálculo a disposición de los investigadores posibilitan en abordaje de problemas con múltiples factores que, incluso en sus versiones más abstractas y simplificadas, encierran poderosas y sugerentes conclusiones. El uso de dispositivos informáticos y, sobre todo, disponer de una gran cantidad de datos que, cada día más, está al alcance de los investigadores, permitirá que, poco a poco, se disponga de modelos más ajustados a la realidad y que arrojen indicios cruciales de cómo deben actuar los gobiernos en casos que requieran intervención.

El fenómeno de las epidemias es un caso paradigmático a este respecto. Con muy pocos parámetros es posible captar la esencia de un fenómeno masivo, tristemente presente en el mundo actual y de consecuencias a menudo devastadoras. En nuestra mano está invertir esfuerzos en mejorar el grado de conocimiento del fenómeno a través del estudio y modelización matemática.

\section{Referencias}

Kermack, W. O., y McKendrick, A. G. (1927). A Contribution to the Mathematical Theory of Epidemics. En VV.AA. Proceedings of the royal society of london. Series A, Containing papers of a mathematical and physical character, 115(772), 700-721.

Aracil, J., y Gordillo, F. (1997). Dinámica de Sistemas (1 ${ }^{\mathrm{a}}$ ed.). Madrid: Alianza Editorial.

Hughes-Hallett, D., Lock, P. F., Gleason, A. M., Flath, D. E., Gordon, S. P., Lomen, D. O., et al. (2017). Applied Calculus. Toronto: John Wiley \& Sons.

Gerald, C. F., y Wheatley, P. O. (2003). Applied Numerical Analysis (7 $7^{\mathrm{a}}$ ed.). Londres: Pearson.

Segarra, J. G. (2002). Vida artificial: del caos al orden. Alzira: Algar.

(C) 2019-2020 Mora-Aguilar; licensee International Journal of Educactional Excellence, Universidad Ana G. Méndez (UAGM). This is an Open Access article distributed under the terms of the Creative Commons Attribution License (http://creativecommons.org/licenses/by/4.0), which permits unrestricted use, distribution, and reproduction in any medium, provided the original work is properly credited. 